\title{
Potential of colloidal or silver nanoparticles to reduce the growth of B16F10 melanoma tumors
}

\author{
Sierra-Rivera C. A., Franco-Molina M. A. ${ }^{*}$ Mendoza-Gamboa E., Zapata-Benavides P., Tamez- \\ Guerra R. S. and Rodríguez-Padilla C.
}

Laboratorio de Inmunología y Virología, Departamento de Microbiología e Inmunología, Facultad de Ciencias Biológicas de la Universidad Autónoma de Nuevo León, San Nicolás de los Garza, N. L. México.

Accepted 26 March, 2013

\begin{abstract}
Previosuly, we reported the cytotoxic effect of colloidal silver (AgC) on MCF-7 breast cancer cell line. However, there is scarce information on its antitumor potential. The aim of this study was to evaluate the anti-tumoral activity of colloidal silver $(\mathrm{AgC})$ or silver nanoparticles (AgNPs) in a B16F10 melanoma mice model. In vitro, B16F10 cells were treated with different concentrations of AgC or AgNPs and cell viability was evaluated by MTT method, both treatments had cytotoxic effects against B16F10 cell line. In vivo, B16F10 melanoma cells $\left(5 \times 10^{5}\right)$ were implanted in six weeks old C57BL/6 mice. About 8 days after cells injection, the subcutaneous treatments were started with AgC or AgNPs, tumor volume and tumor weight were evaluated and the difference of treated groups and control demonstrated that melanoma tumor growth was significantly decreased. Our results suggest that $\mathrm{AgC}$ or $\mathrm{AgNPs}$ could be useful as an antiproliferative drug, inducing an impairment of tumoral growth.
\end{abstract}

Key words: Colloidal silver, silver nanoparticles, melanoma, cancer, tumor.

\section{INTRODUCTION}

The recent increase in the incidence of malignant melanoma urges the development of more specific and effective therapies. Historically, silver has been a major therapeutic agent in medicine, especially in infectious disease, including surgical infections (Alexander, 2009). Since 1990, there has been a resurgence on the use of $\mathrm{AgC}$ as an alternative medicine because of increased resistance of bacteria to antibiotics, and the continuing search for novel and affordable antimicrobial agents. Previously, we reported that $\mathrm{AgC}$ has antitumor activity through induction of apoptosis in MCF-7 breast cancer cell line (Franco-Molina et al., 2010) and other studies with AgNPs, by Sriram et al. (2010) demonstrated the efficacy of biolo-synthesized AgNPs as an antitumor agent against Dalton's lymphoma ascites cell lines in vitro and in vivo and the capacity to affect cellular viability of human colon cancer cells (HT 29) (Sanpui et al., 2011). Despite the fact that nanoparticles and colloidal particles possess great potential for future clinical application therapeutics, and this application generated interest in exploring other metals for potential anti-cancer properties (Bhattacharyya et al., 2011), there is scarce information on $\mathrm{AgC}$ or AgNPs antitumor potential. This study is relevant due to their use within health remedies. The aim of the present study was to determine the effects of $\mathrm{AgC}$ or AgNPs on murine melanoma tumorigenesis under in vitro and in vivo conditions. 


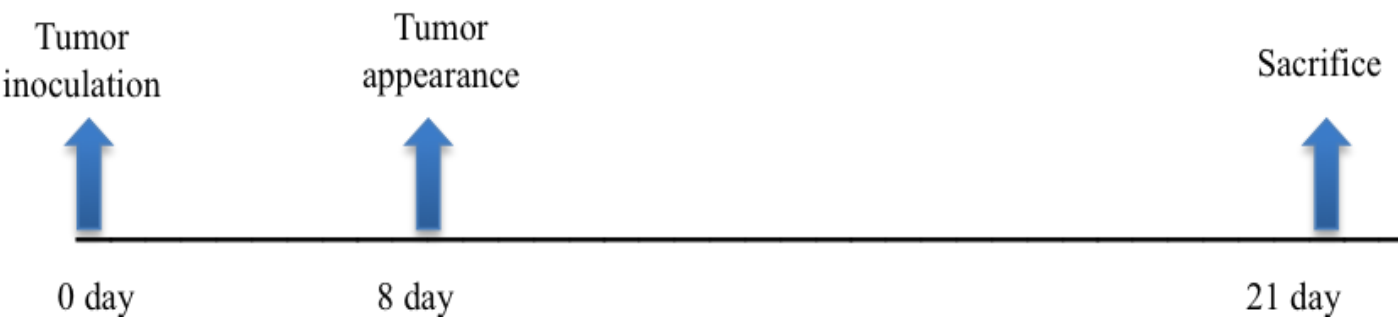

Figure 1. Schematic representation of the treatment protocols. Tumor time-line. $5 \times 10^{5} \mathrm{~B} 16 \mathrm{~F} 10$ cells were inoculated subcutaneously into C57BL/6 mice on day 0 , later beginning on day 8 after tumor cell inoculation, the treatments with AgC $(28 \mathrm{mg} / \mathrm{kg})$ or AgNPs $(1000 \mathrm{mg} / \mathrm{kg})$ were administrated around tumor with daily subcutaneous dose, the mice were monitored until 21 days post-cell inoculation and were finally sacrificed by cervical dislocation.

\section{MATERIALS AND METHODS}

\section{Animals}

In vivo experiments were conducted in male C57BL/6 mice of six weeks old (18 to $25 \mathrm{~g}$ ), housed at $22 \pm 2^{\circ} \mathrm{C}$ under a $12 / 12 \mathrm{~h}$ light/dark cycle with free access to food and water until use. All animal handling and experimental procedures were conducted with prior approval of the ethics committee on animal use of the Facultad de Ciencias Biológicas, Universidad Autónoma de Nuevo León.

\section{AgC or AgNPs}

The grenetine-stabilized $\mathrm{AgC}(120 \mathrm{~nm})$ was purchased from MICRODYN (Mexico, D.F.) as a $0.35 \%$ stock solution. It was filtered and diluted to a concentration of $17.5 \mu \mathrm{g} / \mathrm{mL}$ with DMEM/F-12 supplemented with $10 \%$ FBS. The AgNPs $(10 \mathrm{~nm})$ was purchased from (Nanostructured \& Amorphous Materials Inc. Houston, Tx. USA); $5 \mathrm{mg} / \mathrm{mL}$ stock solution was prepared in DMEM-F12 supplemented with $10 \%$ FBS, previously sonicated during 15 min for its homogenization and sterilized by filtration $(0.2 \mu \mathrm{m}$ filter, Millipore, USA) in vitro for assays. For In vivo studies, $28 \mathrm{mg} / \mathrm{kg}(\mathrm{AgC})$ or $1000 \mathrm{mg} / \mathrm{kg}$ (AgNPs) per mice were daily administered subcutaneously around the tumor.

\section{Cell viability}

Cells $\left(5 \times 10^{3}\right.$ cells/well) were plated on 96 flat-bottom well plates, and incubated $24 \mathrm{~h}$ at $37^{\circ} \mathrm{C}$ in $5 \% \mathrm{CO}_{2}$ atmosphere. After incubation, culture medium was removed, and $\mathrm{AgC}$ diluted in the same medium was added at concentrations ranging from 0 to $17.5 \mu \mathrm{g} / \mathrm{mL}$ and AgNPs at concentrations ranging from 0 to $5 \mathrm{mg} / \mathrm{mL}$. The plates were then incubated for $24 \mathrm{~h}$ at $37^{\circ} \mathrm{C}$, and $5 \% \mathrm{CO}_{2}$ atmosphere. Thereafter, the supernatant was removed and cells were washed twice with DMEM/F-12 medium. Cell viability was determined by the MTT method. Quantification was obtained by the absorbance reading at a wavelength of $570 \mathrm{~nm}$ and cellular viability was expressed as percentage. Results were given as the mean \pm $\mathrm{SD}$ of three independent experiments.

\section{Melanoma cells implant}

All animal procedures were made in Laboratorio de Inmunología de la Facultad de Ciencia Biológicas de la UANL, in accordance with Facultad de Ciencias Biológicas of the UANL Ethics Committee. Briefly, $5 \times 10^{5}$ B16F10 melanoma cells were injected subcutaneously into C57BL/6 mice. When tumors were palpable (around 8 days after implanted) mice were treated around tumor with subcutaneous daily dose of $28 \mathrm{mg} / \mathrm{Kg}$ of $\mathrm{AgC}$ or $1000 \mathrm{mg} / \mathrm{Kg}$ of AgNPs. The mice were monitored until 21 days post-cell inocula-tion and were sacrificed by cervical dislocation (Figure 1). The tumors were surgically collected, and body weight, volume, tumor weight and metastasis were determined (metastasis was deter-mined during the necropsy by findings of tumor cells in muscle, peritoneal cavity, bowel and liver). Tumor volume was recorded using a measuring gauge (PRETUL, USA) using the formula: volume $=$ length $x$ (width) ${ }^{2}$

\section{Statistical analysis}

Data represent the mean $\pm S D$ of triplicates from three independent experiments. Statistical differences were obtained using the analysis of variance, and the Dunnett's tests (SPSS v. 17.0 program). The results were considered statistically significant if the * $p$ value was $<0.05$.

\section{RESULTS}

\section{Cytotoxic activity of AgC or AgNPs on B16F10 melanoma cell line}

$\mathrm{AgC}$ induced dose-dependent cytotoxic effect (7 to 17.5 $\mu \mathrm{g} / \mathrm{mL}$ ) on B16F10 cells (Figure 2). AgNPs induced dosedependent cytotoxic effect $(1.5$ to $5 \mathrm{mg} / \mathrm{mL})$ on B16F10 melanoma cells in $24 \mathrm{~h}$ of incubation (Figure 3 ).

\section{Treatment of B16F10 melanoma tumor}

The B16F10 melanoma model was used to demonstrate the therapeutic value of $\mathrm{AgC}$ or AgNPs. After the tumor appearance by the eight day, the group mice were daily treated with $28 \mathrm{mg} / \mathrm{kg}$ of $\mathrm{AgC}$ or AgNPs $1000 \mathrm{mg} / \mathrm{kg}$, respectively, by subcutaneous route around tumor. The mice were sacrificed at 21 days of treatment (Figure 1). There was no difference regarding the body weight between treatments (control $(25.00 \mathrm{~g} \pm 2.78)$, AgNPs (21.30 $\mathrm{g} \pm 1.14)$ and $\mathrm{AgC}(25.81 \mathrm{~g} \pm 0.39)$ (Table 1 and Figure 4). However, these treatments significantly $(p<0.05)$ decreased the tumor weight $\{(\operatorname{AgNPs}(0.51 \pm 0.22 \mathrm{~g})$ and $\mathrm{AgC}(0.85 \pm 0.64 \mathrm{~g})\}$ when compared with the control (4.97 $\mathrm{g} \pm 0.31)$ (Table 1 and Figure 4); and the tumor 


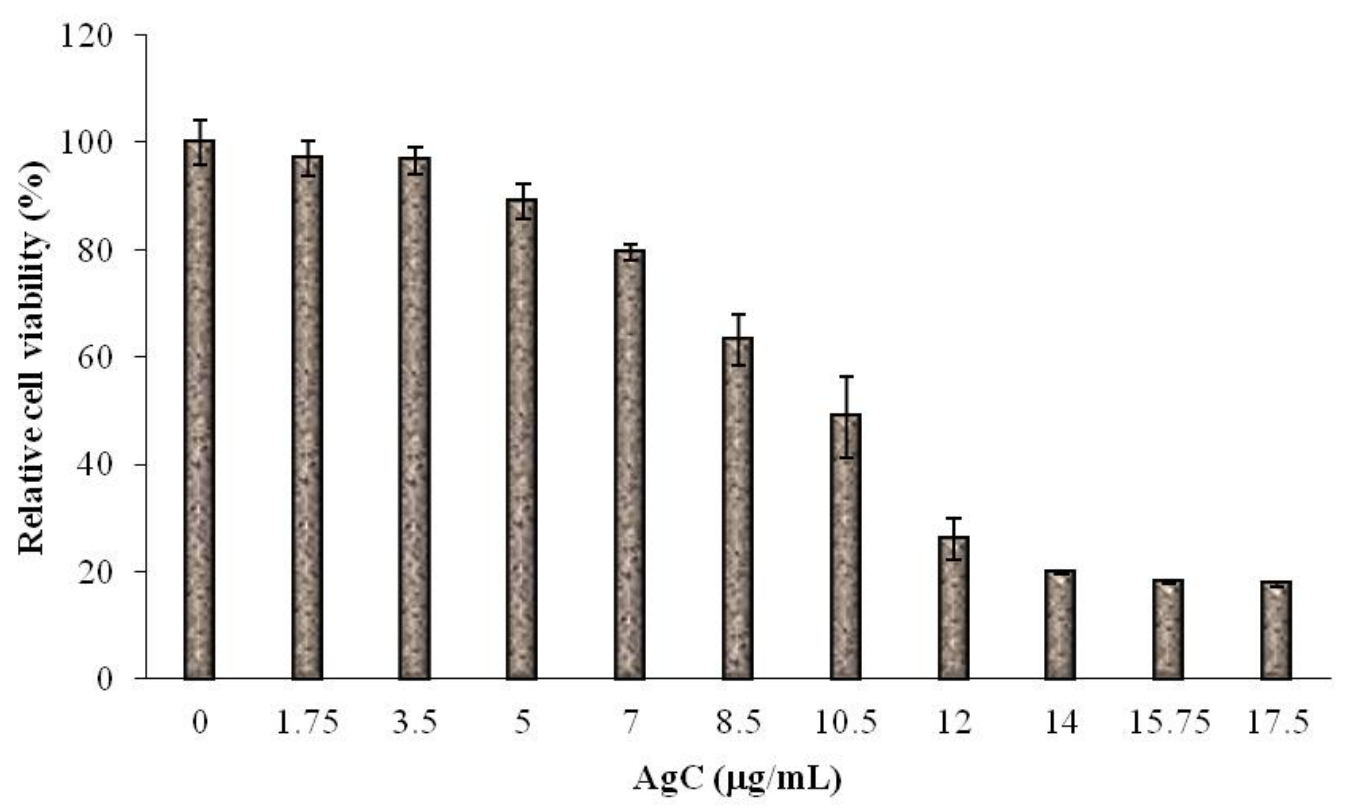

Figure 2. B16F10 cell viability treated with $\mathrm{AgC}$. B16F10 cells $\left(5 \times 10^{3}\right.$ cells/well) were cultured into 96 well plates and incubated overnight. Thereafter, the plates were treated with $\mathrm{AgC}$ concentrations ranging from 0 to $17.5 \mu \mathrm{g} / \mathrm{mL}$, and incubated for $24 \mathrm{~h}$ at $37^{\circ} \mathrm{C}$, and $5 \% \mathrm{CO}_{2}$ atmosphere. Thereafter, a MTT assay was performed. The optical density was determined at $570 \mathrm{~nm}$. Data represent means of triplicate samples with $\pm S D$ indicated. ${ }^{*} p<0.05$ as compared with untreated cells.

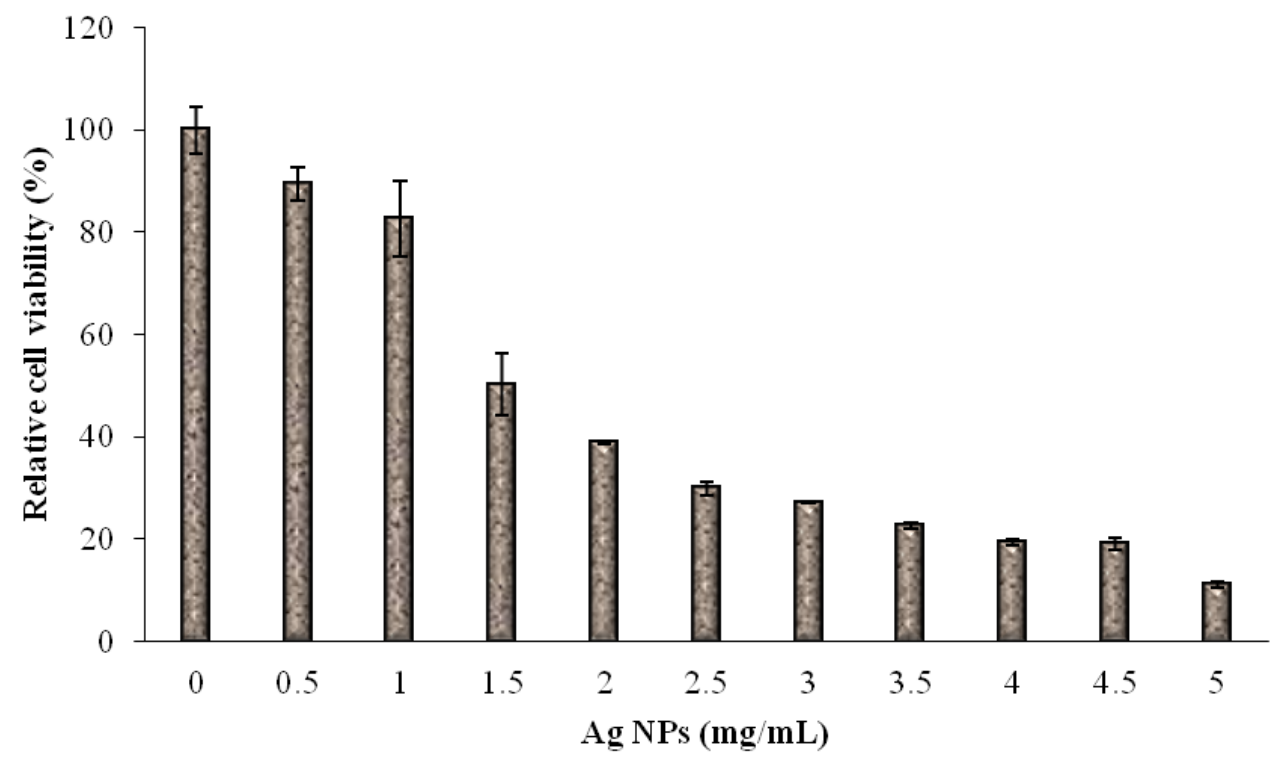

Figure 3. B16F10 cell viability treated with AgNPs. B16F10 cells $\left(5 \times 10^{3}\right.$ cells/well) were cultured into 96 well plates and incubated overnight. Thereafter, the plates were treated with AgNPs concentrations ranging from 0 to $5 \mathrm{mg} / \mathrm{mL}$, and incubated for $24 \mathrm{~h}$ at $37^{\circ} \mathrm{C}$, and $5 \% \mathrm{CO}_{2}$ atmosphere. Thereafter, a MTT assay was performed. The optical density was determined at 570 $\mathrm{nm}$. Data represent means of triplicate samples with $\pm S D$ indicated. ${ }^{*} p<0.05$ as compared with untreated cells.

volume was significantly $(\mathrm{p}<0.05)$ decreased $\{(\mathrm{AgNPs}$ $\left(1.21 \mathrm{~mm}^{3} \pm 0.68\right)$ and $\left.\mathrm{AgC}\left(1.30 \mathrm{~mm}^{3} \pm 0.73\right)\right\}$ when compared with the control $\left(11.01 \mathrm{~mm}^{3} \pm 0.86\right)$ (Table 1 and Figure 4). Regarding to the necropsy findings; the treatments of $\mathrm{AgC}$ or AgNPs prevented the metastasis from muscle, peritoneal cavity, bowel, and liver when compared with control (Table 2). None mice showed tumoral erradication in both groups treated. The mice 

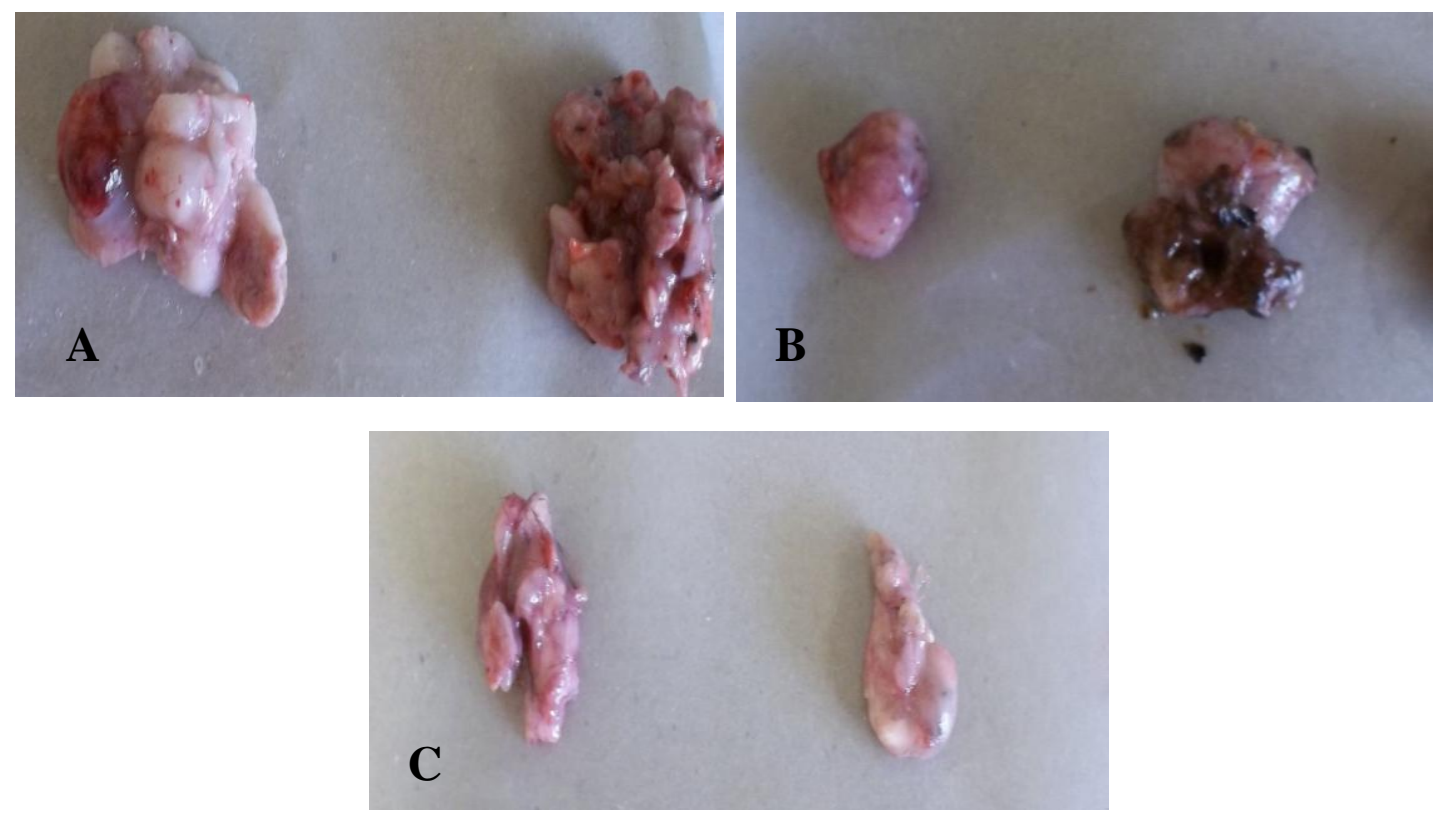

Figure 4. Tumor growth decrease in mice treated with $\mathrm{AgC}$ or AgNPs. C57BL/6 mice bearing B16F10 tumor, were treated daily with AgNP's or AgC at doses of 28 and $1000 \mathrm{mg} / \mathrm{kg}$, respectively. A) Control, B) AgC and C) AgNPs, these pictures are representative mice groups.

Table 1. Comparison of volume-weight of tumors in mice treated with AgC or AgNPs.

\begin{tabular}{lccc}
\hline Treatment & Body weight $(\mathbf{g} \pm \mathbf{S D})$ & Tumor weight $(\mathbf{g} \pm \mathrm{SD})$ & Tumor volume $\left(\mathrm{mm}^{3} \pm \mathbf{S D}\right)$ \\
\hline Control & $25.00 \pm 2.78$ & $4.97 \pm 0.31$ & $11.01 \pm 0.86$ \\
AgC & $25.81 \pm 0.39$ & $0.85 \pm 0.64^{*}$ & $1.30 \pm 0.73^{\star}$ \\
AgNPs & $21.30 \pm 1.14$ & $0.5 \pm 0.22^{*}$ & $1.21 \pm 0.68^{*}$ \\
\hline
\end{tabular}

C57BL/6 mice bearing B16F10 tumor were daily treated with AgNPs or AgC at doses of 1000 or $28 \mathrm{mg} / \mathrm{kg}$, respectively. In this study, the mice were sacrificed at 21 days. ${ }^{*} p<0.05$ as compared to the controls.

Table 2. Incidence of metastasis in mice treated with AgC or AgNPs

\begin{tabular}{lcccc}
\hline Treatment & Muscle & Peritoneal cavity & Bowel & Liver \\
\hline Control & + & + & + & + \\
AgC & - & - & - & - \\
AgNPs & - & - & - & - \\
\hline
\end{tabular}

C57BL/6 mice bearing B16F10 tumor, were treated daily with AgNPs or AgC at doses of 1000 or 28 $\mathrm{mg} / \mathrm{kg}$, respectively. In this study, the mice were sacrificed by cervical dislocation at 21 days; and the metastasis was determined during the necropsy in muscle, peritoneal cavity, bowel and liver. +: Metastasis, - : without metastasis.

treated with $\mathrm{AgC}$ showed a skin induration like fibrosis in the zone treated for five days, this condition was observed until sacrifice; the mice treated with AgNPs were not affected by this symptoms.

\section{DISCUSSION}

Skin cancer is the most common form of cancer in the United States. More than 3.5 million skin cancers in over two million people are diagnosed annually. Each year there are more new cases of skin cancer than the combined incidence of cancers of the breast, prostate, lung and colon. An estimated 123,590 new cases of melanoma were diagnosed in the US in 2011: 53,360 noninvasive (in situ) and 70,230 invasive, with nearly 8,790 resulting in death (http://www.skincancer.org). Some cytotoxic agents used for its treatment are costly and known to induce several side effects such as myelosup- 
pression, anemia and most importantly the generation of cellular resistance. For this, it is important to find alternative therapies or drugs to overcome these drawbacks (Kim et al., 2007). Since ancient times, the silver has been used to treat numerous diseases, mainly used in antimicrobial agents, in treating wounds, burns and catherter related infections (AshaRani et al., 2009), however; it was until only a few years ago that there was boom in taking different silver particles due to the rate of exposure increasing progresively over the years when engineered nanomaterials were extensively used in a variety of industries including medical applications (AshaRani et al., 2012). The use of smaller particles have a wider tissue distribution, penetrate further within the skin and intestine, are internalised to a greater extent, and have a larger toxic potency (Johnston et al., 2010). So the study of different silver particles is vital to explore their therapeutic potential. Previously, we reported the antitumor activity of colloidal silver on MCF-7 human breast cancer cells (Franco-Molina et al., 2010), and for this reason we decided to continue with a tumor model In vivo. In the present study, our In vitro results demonstrated that $\mathrm{AgC}$ or AgNPs significantly decreased in a dose-dependent manner $(p<0.05)$, the growth of B16F10 melanoma cells. The effects of cytotoxicity are similar to those shown by other studies (Hsin et al., 2008) and the mechanism of cell death probably are due to decreased mitochondrial membrane potential, inducing apoptotic death (Franco-Molina et al., 2010). Although, the exact mechanism of action of silver particles is unknown; some reports showed that AgNP uptake occurs mainly through endocytosis where clathrin mediated process and macropinocytosis were involved, the nuclear deposition of AgNP is unknown, but the AgNP treatment leads to changes in the cell membrane permeability, facilitating the entry of $\mathrm{Ca}^{+}$ions which activate enzymes like proteases and endonuclease that increase toxicity, resulting in mitochondrial membrane dysfunction and reactive oxygen species production and oxidative stress, damage to DNA can be induced through binding of DNA or via oxidative to DNA, reducing DNA synthesis and producing chromosomal aberrations, errors in chromosome segregation and production of micronuclei, leading to cell death (AshaRani et al., 2009), mainly observed in tumor cells and not in normal cells (Franco-Molina et al., 2010). It is important to notice that major doses were used to induce cytotoxic effect by AgNPs ( 1.5 to $5 \mathrm{mg} / \mathrm{mL}$ ) when compared with $\mathrm{AgC}$ (7 to $17.5 \mu \mathrm{g} / \mathrm{mL}$ ) on cancer cells. This findings were probably due to the fact that AgNPs treated cells have limited exposure to $\mathrm{Ag}$ ions because AgNPs solution contained a minimun amount of free $\mathrm{Ag}$ ions. However, it has been suggested that AgNPs and Ag can induce cell death in vitro through a ROS production. It has been demonstrated that there are some differences in their mechanism of action, example is that $\mathrm{Ag}$ induced metallothionein $1 \mathrm{~b}$ (MT1b) and AgNPs did not. Ag also is capable of inducing a major production of oxidative stress related glutathione peroxidase and catalase expression compared with AgNPs. This mechanism of action could indicate that $\mathrm{AgC}$ appeared more toxic than AgNPs such has been demonstrated by Hsin et al., 2008.

"In vivo" we found that AgC or AgNPs have the potential to impair the growth tumor, since AgNPs is better than $\mathrm{AgC}$ treatment in reducing the tumoral volume and weight. These finding could be correlated with another study where the AgNPs had the potential of inhibiting the VEGF in a model employing bovine retinal endothelial cells in vitro and angiogenesis in a mice model in vivo (Gurunathan et al., 2009). At the beginning of the study, we observed that intraperitoneal injection of $\mathrm{AgC}$ (28 $\mathrm{mg} / \mathrm{kg}$ ) induced mice exhibited nervous symptoms after $15 \mathrm{~s}$ of administration, like jumping and disnea by $10 \mathrm{~min}$ and lethargy during all day long (data not shown), by this reason the use of subcutaneous administration at doses of $28 \mathrm{mg} / \mathrm{kg}$, without side effects was decided, avoiding increases of the doses like that used with AgNPs. There are reports that show adverse effects when doses higher than $100 \mathrm{mg} / \mathrm{kg}$ of $\mathrm{AgC}$ were used (Faust, 1992). And the adverse effects could be possible because the $\mathrm{Ag}$ can enter through the blood-brain barrier and accumulate in large motoneurones in the brain stem and spinal cord, neurons in cerebellar nuclei and glia; and the toxic symptoms such as cerebral ataxia are associated with prolonged exposure to silver (Panyala et al., 2008), which is different from the findings previously mentioned by us.

In this experiment, we used the highest doses reported for AgNPs because in a study by Rahman et al. (2009) on the effects of AgNPs (25 nm) on gene expression in different regions of the mouse brain where the particles were administered to adult male mice route intraperitoneal injection at doses of 100,500 , or $1000 \mathrm{mg} / \mathrm{kg}$ for 24 $\mathrm{h}$, array data indicated changes in the expression of genes in the caudate nucleus, frontal cortex and hippocampus of mice treated with the AgNPs. Analysis of these changes led the authors to suggest that AgNPs may produce neurotoxicity by stimulating oxidative stress generation and altered gene expression, leading to apoptosis (Rahman et al., 2009). In the present study, despite the use of AgNPs daily for thirteen days, we did not find adverse effects, like nervous symptoms associated at its administration.

Although, the mechanism of the antitumoral action of $\mathrm{AgC}$ or AgNPs is not properly understood, it has been reported that heavy metals react with proteins by getting attached to the thiol group and the proteins get inactivated through a mechanism implicated in avoiding the cellular proliferation of cancer cells (Liau et al., 1997).

With these results, we can confirm the potential of $\mathrm{AgC}$ or AgNPs on this melanoma tumor model suggesting them as a potential agent for use in cancer treatment.

\section{REFERENCES}

Alexander JW (2009). History of the Medical Use of Silver. Surgical 
Infection, 10: 289-292.

AshaRani P, Hande MP, Valiyaveettil S (2009). Anti-proliferative activity of silver nanoparticles. BMC Cell Biology. 10:65.

AshaRani P, Sethu S, Lim HK, Balaji G, Valiyaveetil S, Hande MP (2012). Differential regulation of intracellular factors mediating cell cycle, DNA repair and inflammation following exposure to silver nanoparticles in human cells. Genome integrity. 3:2.

Bhattacharyya S, Kudgus RA, Bhattacharya R, Mukherjee P (2011). Inorganic nanoparticles in cancer therapy. Pharm Res. 28: 237-59.

Faust RA (1992). Toxicity summary for silver. Chemical Hazard Evaluation and Communication Group. Biomedical and Environmental Information Analysis Section Health and Safety Research Division. Oak Ridge Reservation Environmental Restoration Program. Tennessee.

Franco-Molina MA, Mendoza-Gamboa E, Sierra-Rivera CA, GómezFlores RA, Zapata-Benavides P, Castillo-Tello P, Alcocer-González JM, Miranda-Hernández DF, Tamez-Guerra RS, Rodríguez-Padilla C (2010). Antitumor activity of colloidal silver on MCF-7 human breast cancer cells. J. Exp. Clin. Cancer Res. 29: 148.

Gurunathan S, Lee KJ, Kalishwaralal K, Sheikpranbabu S, Vaidyanathan R, Eom SH (2009). Antiangiogenic properties of silver nanoparticles. Biomaterials. 30: 6341-50.

Hsin YH, Chen CF, Huang S, Shih TS, Lai PS, Chueh PJ (2008). The apoptotic effect of nanosilver is mediated by a ROS- and JNKdependent mechanism involving the mitochondrial pathway in NIH3T3 cells. Toxicol Lett. 179:130-9.

Johnston HJ, Hutchison G, Christensen FM, Peters S, Hankin S, Stone $\mathrm{V}$ (2010). A review of the in vivo and in vitro toxicity of silver and gold particulates: Particle attributes and biological mechanisms responsible for the observed toxicity. Crit Rev in Toxicol. 40: 328-46.
Kim DW, Hong GH, Lee HH, Choi SH, Chun BG, Won CK, Hwang IK, Won MH (2007). Effect of colloidal silver against the cytotoxicity of hydrogen peroxide and naphthazarin on primary cultured cortical astrocytes. Int. J. Neurosci. 117: 387-400.

Liau SY, Read DC, Pugh WJ, Furr JR, Russell AD (1997). Interaction of silver nitrate with readily identifiable groups: relationship to the antibacterial action of silver ions. Lett. Appl. Microbiol. 25:279-83.

Panyala NR, Peña-Méndez EM, Havel J (2008). Silver or silver nanoparticles: a hazardous threat to the environment and human health? J. Appl. Biomed. 6: 117-129.

Rahman MF, Wang J, Patterson TA, Saini UT, Robinson BL, Newport GD, Murdock RC, Schlager JJ, Hussain SM, Ali SF (2009). Expression of genes related to oxidative stress in the mouse brain after exposure to silver-25 nanoparticles. Toxicol. Lett. 187: 15-21.

Sanpui P, Chattopadhyay A, Ghosh SS (2011). Induction of Apoptosis in Cancer Cells at Low Silver Nanoparticle Concentrations using Chitosan Nanocarrier. Appl. Mater. Interfaces. 3: 218-228.

Sriram MI, Kanth SB, Kalishwaralal K, Gurunathan S (2010). Antitumor activity of silver nanoparticles in Dalton's lymphoma ascites tumor model. Int. J. Nanomed. 5: 753-762. 